\title{
Fish Species Composition, Distribution and Diversity in Two Selected Rivers of Mt. Hamiguitan Range Wildlife Sanctuary (HRWS), San Isidro, Davao Oriental, Mindanao, Philippines
}

\author{
VICTORIA T. QUIMPANG \\ ORCID No. 0000-0003-1992-6359 \\ vtquimpang@yahoo.com \\ Department of Biology, College of Arts in Sciences, \\ Central Mindanao University, Musuan, Maramag, \\ Bukidnon, Philippines \\ EINSTINE M. OPISO \\ ORCID No. 0000-0001-6806-4703 \\ einstineop@gmail.com \\ Geo-environmental Group, College of Engineering, \\ Central Mindanao University, Musuan, Maramag, \\ Bukidnon, Philippines
}

\section{ROMEO M. TUBONGBANUA, JR. \\ ORCID No. 0000-0002-5429-1275 \\ venomgoya@yahoo.com}

Center for Biodiversity Research and Extension in Mindanao,

Central Mindanao University, Musuan, Maramag,

Bukidnon, Philippines

\author{
MARY COR S. SALOLOG \\ ORCID No. 0000-0002-3405-8687 \\ smarycor@gmail.com
}

Center for Biodiversity Research and Extension in Mindanao,

Central Mindanao University, Musuan, Maramag,

Bukidnon, Philippines 


\author{
VICTOR B. AMOROSO \\ ORCID No. 0000-0001-8865-5551 \\ victorbamoroso@gmail.com \\ Geo-environmental Group, College of Engineering, \\ Center for Biodiversity Research and Extension in Mindanao, \\ Central Mindanao University, Musuan, Maramag, \\ Bukidnon, Philippines
}

\begin{abstract}
The composition, distribution and diversity of fish species in Dumagooc and Maug Rivers of Mt. Hamiguitan Range Wildlife Sanctuary (HRWS) were examined in the months of February, May and October, 2015. Backpack electrofishing was used to collect samples from four study stations along the river courses. A total of 33 fish species from 15 families with 991 individuals was recorded. It supports one endemic species, 28 native species and four introduced species. The Eleotridae family was dominant in Dumagooc and Maug Rivers. However in Dumagooc River, the sleeping cod, Oxyelotris lineonata was the leading species. Thus, mottled eel (A. marmorata) was distributed along all the stations while blue neon goby (Stiphonodon atropurpureus) was confined in the upper stream. On the other hand the leading species in Maug River was mottled eel, (Anguilla marmorata.). Furthermore, the common barb (Puntius bantolanensis) was found in the upper middle stream and downstream while Leopard pleco (Pterygoplicthys pardalisi) was noted only in the upper middle stream of Maug River. High species value of $\mathrm{H}^{\prime}=1.199$ was found in Dumagooc River. These information would serve as basis for the formulation of protection and conservation policies for the fish species and its habitats before it becomes extinct.
\end{abstract}

Keywords: Endemic species; River; Fish species; Composition; Distribution 


\section{INTRODUCTION}

Mount Hamiguitan Range Wildlife Sanctuary lies in the province of Davao Oriental in the southernmost part of the Philippines. It was declared as UNESCO and ASEAN heritage sites in 2014. It provides shelter to globally threatened and endemic flora and fauna which include critically endangered trees and plants. It is also the home of the famous Philippine eagle and Philippine cockatoo (Medina et al. 2015). Its striking feature is it has the largest and the most unique pygmy forest from lowland to the summit of the mountain range with century old trees thriving in a highly basic and ultramafic soil (Relox et al. 2011). It is the major headwater of the major rivers which are observed to be clear and of good quality that support freshwater aquatic life.

The MHRWS is currently facing threats due to forest degradation and conversion of forested land to agriculture, shifting cultivation and over-collection (Amoroso and Aspiras 2011). As a result, some species may be lost before they are recorded, studied and conserved especially the fishes in aquatic ecosystem. The fishes are largely affected by the uncontrolled habitat degradation which causes flooding and contamination of the river system. These fishes can be used as biological indicators to show the level of aquatic pollution and environmental quality.

\section{OBJECTIVES OF THE STUDY}

This study aimed to examine the fish species composition, distribution and diversity in the two rivers of the Mt. Hamiguitan Range Wild Sanctuary.

\section{MATERIALS AND METHODS}

\section{Study Area}

The study was carried out at the two rivers in Mt. Hamiguitan, one of the Long Term Ecological Research (LTER) sites in Mindanao (Figure 1). Mt. Hamiguitan Range is located on the southeastern side of Davao Oriental and was declared as World Heritage Park and Asean Heritage Park in year 2014. The headwaters of different rivers and creeks are in this site. One of these rivers provides water for domestic use and irrigation in the lowland area of the municipalities of Governor Generoso and San Isidro. 

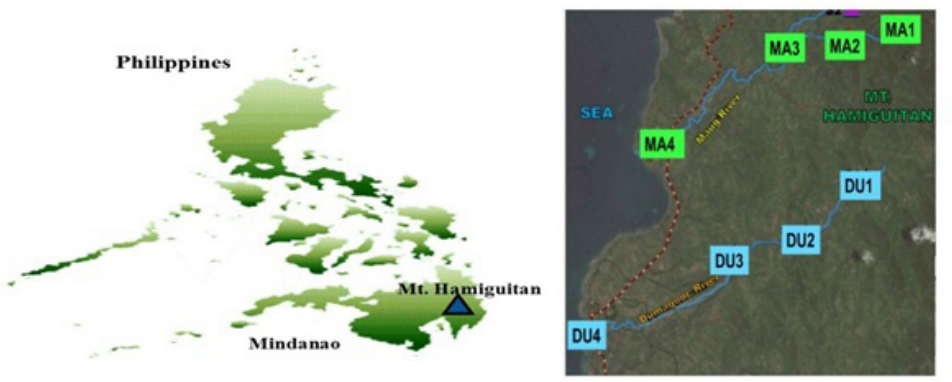

Figure1. Location map of the Mt. Hamiguitan Mindanao LTER mountain and the sampling stations along the upper stream to downstream courses (Google Earth, 2014) Dumagooc ( $\square$ ) Maug ( $\square$ ).

Table 1. Elevation, location and land uses of selected study sites

\begin{tabular}{|c|c|c|c|c|}
\hline Site & $\begin{array}{l}\text { Elevation } \\
\text { (masl) }\end{array}$ & Location & & Surrounding land uses \\
\hline \multicolumn{5}{|l|}{$\begin{array}{l}\text { Dumagooc River (Mt. } \\
\text { Hamiguitan) }\end{array}$} \\
\hline DU1 & 197 & $06^{\circ} 41.130^{\prime}$ & $126^{\circ} 07.720^{\prime}$ & Forests; shrubs; \\
\hline DU2 & 146 & $06^{\circ} 40.130^{\prime}$ & $126^{\circ} 06.600^{\prime}$ & Forest, residential; \\
\hline DU3 & 104 & $06^{\circ} 39.129^{\prime}$ & $126^{\circ} 05.506^{\prime}$ & $\begin{array}{l}\text { Agro-forestry; residential; irrigation dam; small } \\
\text { scale quarry }\end{array}$ \\
\hline DU4 & 36 & $06^{\circ} 38.925^{\prime}$ & $126^{\circ} 04.328^{\prime}$ & Agro-forestry; residential; bridge; road, \\
\hline $\begin{array}{l}\text { Maug River ( Mt. } \\
\text { Hamiguitan) }\end{array}$ & & Latitude & Longitude & \\
\hline MA1 & 565 & $06^{\circ} 43.801^{\prime}$ & $126^{\circ} 09.352^{\prime}$ & Forest \\
\hline MA2 & 397 & $06^{\circ} 44.143^{\prime}$ & $126 .{ }^{\circ} 08.538^{\prime}$ & Agro-forestry; firewood source \\
\hline MA3 & 85 & $06^{\circ} 43.490^{\prime}$ & $126^{\circ} 07.442^{\prime}$ & $\begin{array}{l}\text { Residential; domesticated animals around the } \\
\text { area; laundry and washing area. }\end{array}$ \\
\hline MA4 & 44 & $06^{\circ} 41.968^{\prime}$ & $126^{\circ} 05.517^{\prime}$ & $\begin{array}{l}\text { Large scale quarry; residential; agricultural } \\
\text { land; pig pen. }\end{array}$ \\
\hline
\end{tabular}

\section{Fish Collection, Handling, Preservation and Storage}

Fish was collected from January to October 2015 by using backpack electrofishing (Figure 2A) with 12 volts battery (Helfman 1999). Collected fishes were then placed in a bucket with water to let them stay alive until they fully recovered from the shock (Figure $2 \mathrm{~B}$ ). Upon capture, all fishes were handled with care to prevent water burn. Voucher specimens of each of the species were preserved in $100 \%$ ethanol for further studies in the laboratory. Others were returned alive into the water of the sampling area. 


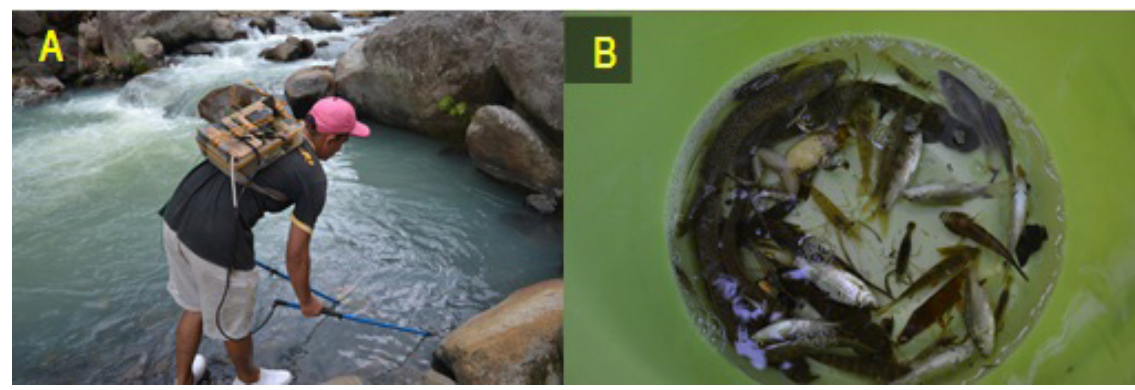

Figure 2. (A) Backpack Electrofishing; B) Captured Fish from Electrofishing in a Bucket.

\section{Fish Morphometry, Description, and Identification}

Morphometrics of the fishes such as total length $(\mathrm{cm})$ and body weight $(\mathrm{g})$ were recorded. A ruler was used to measure the total length $(\mathrm{cm})$ of the fish from its closed snout to the jointed fish tail joining for fork tail shape (Figure 3.A). A small container with water enough for the size of the fish was weighed first to get the initial weight before putting the fish for final weight. Initial weight was then subtracted from the final weight to get the body mass of the fish (Figure 3.B).

Field description of the live fish was done by noting the color, number of fins, and barbells if present, shape of the tail and head, body structure and mouth (Figure 3.C). Species were then identified to species level using identification keys for Philippine freshwater fishes using primarily Herre 1953, Paller et al. 2011, Hubilla 2007, and Froese and Pauly, (2016).
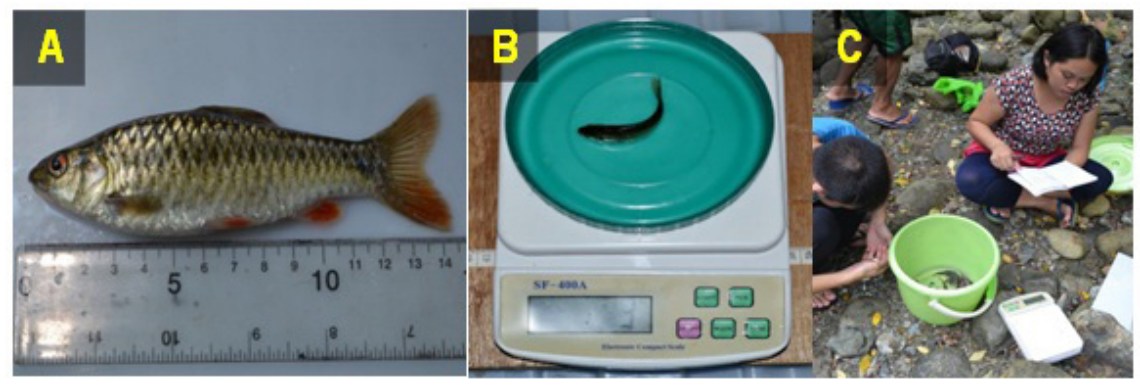

Figure 3. (A) Measuring the Length of Captured Fish;

(B) Weighing of Captured Fish; (C) Noting Field Description of Captured Fish. 


\section{Community Structure Analysis}

Fish individuals collected were counted according to species and families. Shannon-Weiner Index Diversity and Abundance plot were determined from the samples using BioDiversity Pro software version 2.

\section{Fish Species Indicators}

The status of the fishes whether native, endemic or introduced was noted based on listing and classification of Fishbase ver.10, 2015.

\section{RESULTS AND DISCUSSION}

A total of 33 fish species in 15 families comprising 991 fish individuals was collected from the Maug and Dumagooc Rivers (Plate 1, Table 2). This number represents $9.22 \%$ of 358 fish species recorded in the Philippines. The result is much higher than 27 species recorded by Quimpang et al. (2015) in the same rivers in Mt. Hamiguitan and the 16 species recorded by Paller et al. (2011) in Mt. Makiling Forest Reserve. However, this result is lower compared with the 38 species found in Bugang River, Negros Occidental (Guzman and Capaque 2014), 55 species in Bago river in Negros Occidental (Pacalioga et al. 2010) and 89 species recorded in Negros and Siquijor Islands (Bucol and Carumbana 2010). The Maug and Dumagooc rivers support one endemic species, 28 native species and four introduced fish species. The native species represents $12.67 \%$ of 221 native fish species here in the Philippines, while the endemic species Puntius bantolanensis represents $2.27 \%$ of 44 fish species and introduced species represent $8.33 \%$ of 48 species recorded in the country.

The high number of native species can be attributed to the ingression of estuarine species especially in the down stations of both rivers. The down station (DU4) of Dumagooc River was very near the sea, where most of the recorded native species were from family Eleotridae and Gobiidae. Species from these families migrate to freshwater systems from sea to brackish water and vice versa (Herre 1953). The result is somewhat similar to the result found by Bucol and Carumbana (2010) in Negros and Siquijor Islands, where Gobiidae and Eleotridae were the most species rich families. 

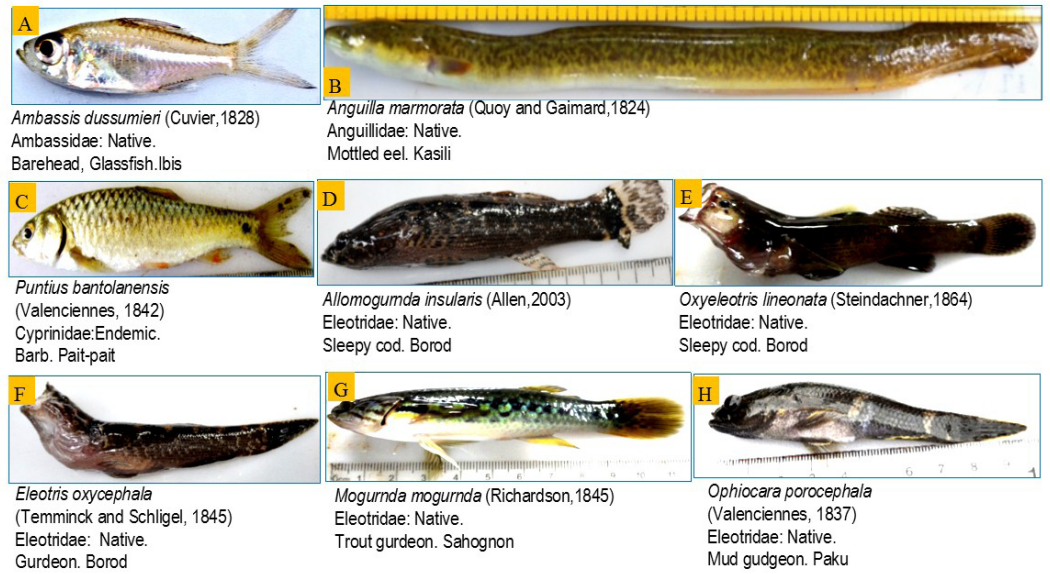

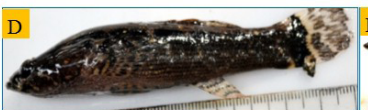

Allomogumda insularis (Allen, 2003)

Eleotridae: Native.

Sleepy cod. Borod

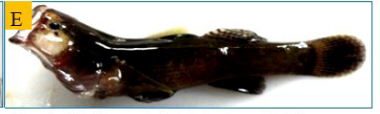

Oxyeleotris lineonata (Steindachner, 1864)

Eleotridae: Native. Sleepy cod. Borod

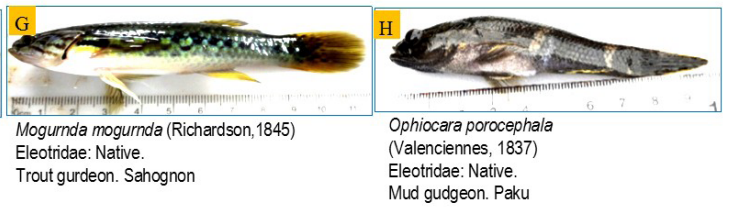

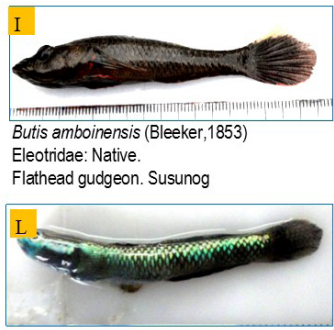

Stiphodon atropurpureus

(Herre, 1927)Gobiidae: Native.

Blue neon goby. Bablo

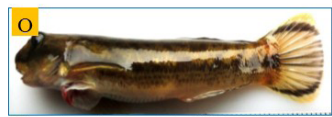

Sicyopterus lagocephalus (Pallas, 1770)

Gobiidae: Native.

Round red-tailed goby. Balolo

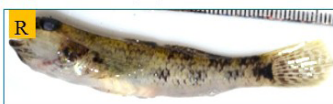

Acentrobius janthinopterus (Bleeker, 1853) Gobiidae: Native.

Robust mangrove goby. Bia itom

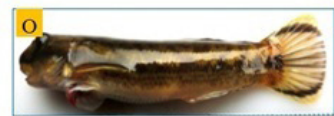

Sicyopterus lagocephalus (Pallas, 1770)

Gobiidae: Native.

Round red-tailed goby. Balolo

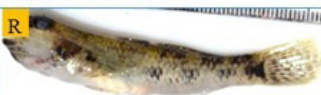

Acentrobius janthinopterus (Bleeker, 1853)

Gobiidae: Native.

Robust mangrove goby. Bia itom

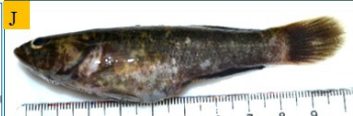

Eleotris acanthopoma (Bleeker, 1853)

Eleotridae: Native.

Spine-cheek gudgeon. Sahognon itom

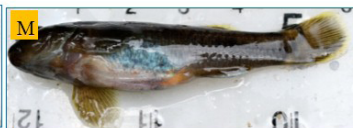

Awaous grammepomus (Bleeker, 1849

Gobiidae: Native

Goby. Bia

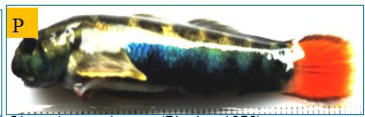

Sicyopterus micrunus (Bleeker,1853)

Gobiidae: Native.

Clinging Blue Goby. Balolo
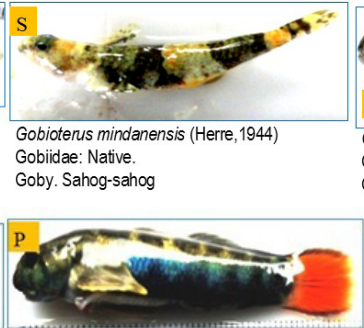

Sicyopterus micrunus (Bleeker, 1853)

Gobiidae: Native.

Clinging Blue Goby. Balolo

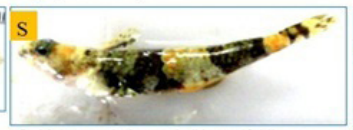

Gobioterus mindanensis (Herre, 1944)

Gobiidae: Native.

Goby. Sahog-sahog

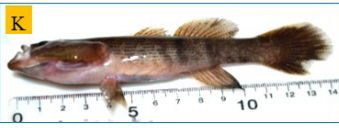

Eleotris fusca (Foster, 1801)

Eleotridae: Native.

Dusky sleeper. Borod-borod

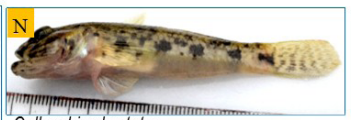

Callogobius hastatus

(McKinney and Lachner, 1978)

Gobiidae: Native.

Spearfin goby. Kalubluban

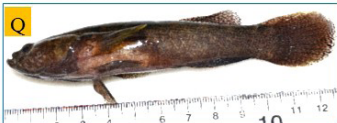

Callogobius maculipinnis (Fowler, 1978)

Gobiidae: Native.

Ostrich goby. Kalubluban itom

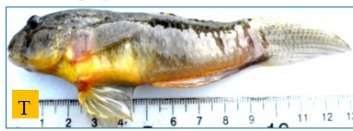
Oligolepis acutippenis (Valenciennes, 1837)

Gobiidae: Native.

Goby. Bia dilaw

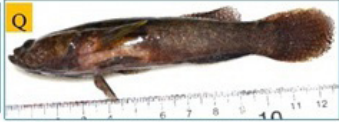

Callogobius maculipinnis (Fowler, 1978)

Gobiidae: Native.

Ostrich goby. Kalubluban itom

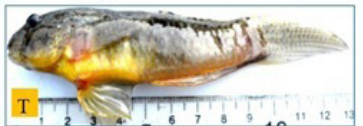

Oligolepis acutippenis (Valenciennes, 1837)

Gobiidae: Native.

Goby. Bia dilaw 


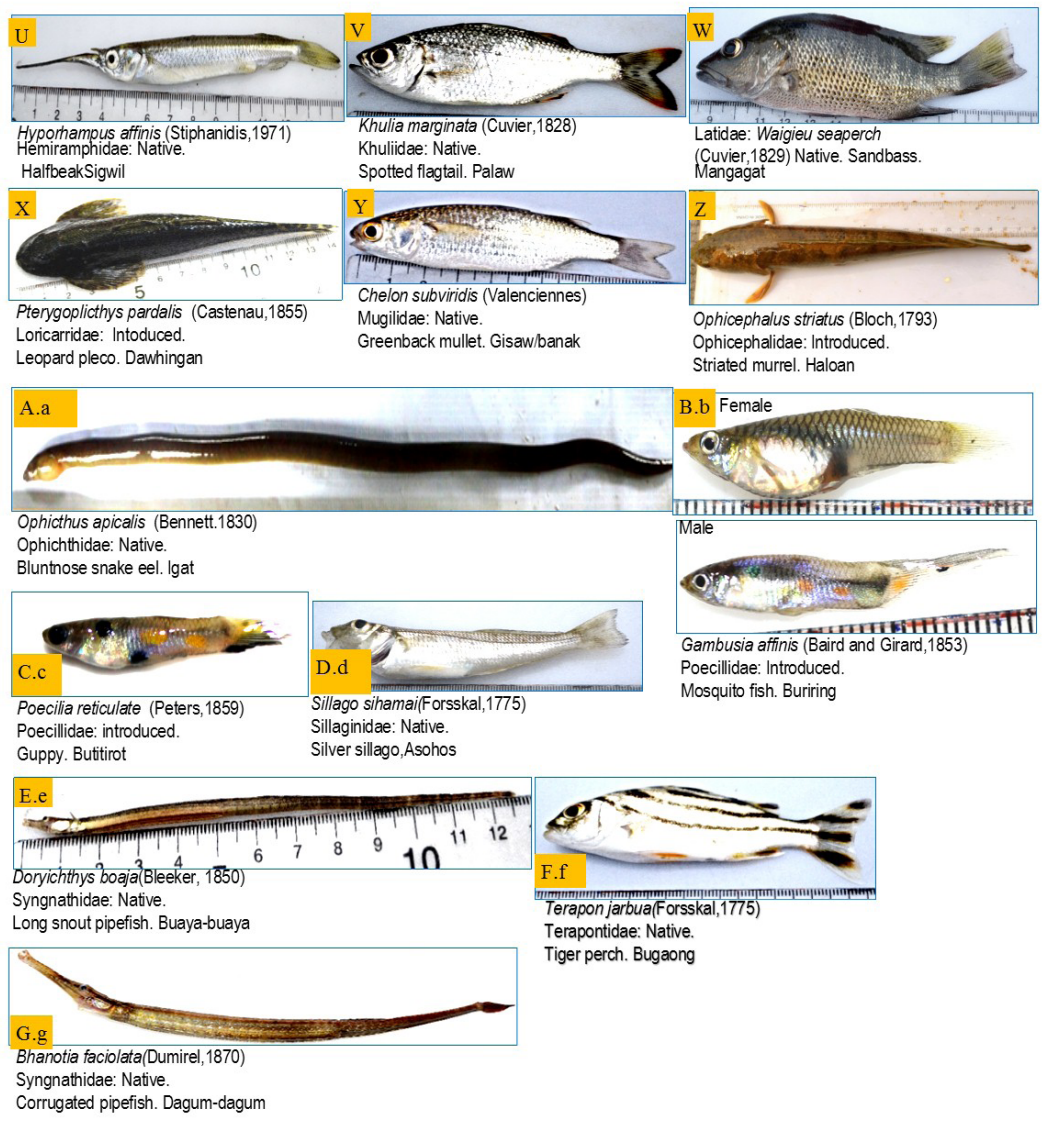

Plate 1. Fish Species Composition of the Two Rivers of Mt. Hamiguitan Wildlife Sanctuary, Mindanao LTER sites Philippines (February-May - October, 2015).

The Dumagooc River harbors more species (33) and individuals (541) than the Maug River, 15 species and 450 individuals. Sleeping cod, Oxyeleotris lineonata, a native species, leads the catch. Fishes are present in all sampling sites of Dumagooc River, with the down station (S4) having the highest total fish individuals.

The native eel, Anguilla marmorata, dominated the catch in Maug River, followed by spotted flagtail, Kublia marginata. However, the collected fish species were generally smaller in terms of length and lighter in terms of weight. $A$. 
marmorata was the biggest at $49 \mathrm{~cm}$ long and 54 grams, while Poecilia reticulate was the smallest at $1.2 \mathrm{~cm}$ long and less than $1 \mathrm{~g}$.

Table 2. Fish Species Composition and Individual Counts of Fishes at the Two Rivers of Mt. Hamiguitan Wildlife Sanctuary, LTER Site Philippines (January-October 2015) *Fishbase, 2016.

\begin{tabular}{|c|c|c|c|c|c|c|c|}
\hline Scientific Name & Family & $\begin{array}{l}\text { Common } \\
\text { Name }\end{array}$ & Occurrence * & $\begin{array}{l}\text { Maug } \\
\text { River }\end{array}$ & $\begin{array}{c}\text { Dumagooc } \\
\text { River }\end{array}$ & $\begin{array}{l}\text { Mean } \\
\text { length, } \\
\mathrm{cm}\end{array}$ & $\begin{array}{c}\text { Mean } \\
\text { weight, } \\
\mathrm{g}\end{array}$ \\
\hline & & & & Total & Total & & \\
\hline $\begin{array}{l}\text { 1. Ambassis dussumieri } \\
\text { (Cuvier, 1828) }\end{array}$ & Ambassidae & $\begin{array}{l}\text { Barehead } \\
\text { glassfish }\end{array}$ & Native & 0 & 9 & $6-12$ & $5-11$ \\
\hline $\begin{array}{l}\text { 2. Anguilla marmorata (Quoy \& } \\
\text { Gaimard, 1824) ) }\end{array}$ & Anguillidae & Mottled eel & Native & 103 & 38 & $8.9-49$ & $12-67$ \\
\hline $\begin{array}{l}\text { 3. Puntius bantolanensis } \\
\text { (Valenciennes, 1842) syn. } \\
\text { Barbus bantolanensis } \\
\text { (Valenciennes, 1842) }\end{array}$ & Cyprinidae & Common barb & Endemic & 55 & 75 & $3.2-13.2$ & $1<-14$ \\
\hline $\begin{array}{l}\text { 4. Allomogurnda insularis } \\
\text { (Allen,2003) }\end{array}$ & Eleotridae & Sleepy cod & Native & 26 & 2 & $4.7-6.3$ & $5-7$ \\
\hline $\begin{array}{l}\text { 5. Oxyeleotris lineonata } \\
\text { (Steindachner, 1867) }\end{array}$ & Eleotridae & Sleepy cod & Native & 49 & 88 & $3.8-6.1$ & $4-5$ \\
\hline $\begin{array}{l}\text { 6. Eleotris oxycephala } \\
\text { (Temminck and } \\
\text { Schligel,1845) }\end{array}$ & Eleotridae & Gurdeon & Native & 18 & 5 & $3.1-6.7$ & $3-7$ \\
\hline $\begin{array}{l}\text { 7. Mogurnda mogurnda } \\
\text { (Richardson, 1845) }\end{array}$ & Eleotridae & Trout gurdeon & Native & 43 & 76 & $4.2-8.4$ & $4-9$ \\
\hline $\begin{array}{l}\text { 8. Ophiocara porocephala } \\
\text { (Valenciennes, 1837) }\end{array}$ & Eleotridae & Mud gudgeon & Native & 0 & 4 & $3.8-7.5$ & $3-7$ \\
\hline $\begin{array}{l}\text { 9. Butis amboinensis } \\
\text { (Bleeker, 1853) }\end{array}$ & Eleotridae & $\begin{array}{l}\text { Flathead } \\
\text { gudgeon }\end{array}$ & Native & 0 & 1 & 5.9 & 6 \\
\hline $\begin{array}{l}\text { 10. Eleotris acanthopoma } \\
\text { (Bleeker, 1853) }\end{array}$ & Eleotridae & $\begin{array}{l}\text { Spine-cheek } \\
\text { gudgeon }\end{array}$ & Native & 0 & 2 & $2.5-4.8$ & $2-4$ \\
\hline 11. Eleotris fusca (Foster, 1801) & Eleotridae & Dusky sleeper & Native & 0 & 21 & $1.5-5$ & $1<-4$ \\
\hline $\begin{array}{l}\text { 12. Stiphodon atropurpureus } \\
\text { (Herre, 1927) }\end{array}$ & Gobiidae & $\begin{array}{l}\text { Blue neon } \\
\text { goby }\end{array}$ & Native & 0 & 28 & $1.3-3.4$ & $1<-2$ \\
\hline $\begin{array}{l}\text { 13. Sicryopterus micrurus } \\
\text { (Bleeker, 1853) }\end{array}$ & Gobiidae & $\begin{array}{l}\text { Cobalt blue } \\
\text { gobyl } \\
\text { Clinging goby }\end{array}$ & Native & 11 & 35 & $2.1-5.7$ & $2-6$ \\
\hline $\begin{array}{l}\text { 14. Sicryopterus lagocephalus } \\
\text { (Pallas, 1770) }\end{array}$ & Gobiidae & $\begin{array}{l}\text { Round red- } \\
\text { tailed goby }\end{array}$ & Native & 13 & 28 & $2.9-7.3$ & $2-6$ \\
\hline $\begin{array}{l}\text { 15. Awaous grammepomus } \\
\text { (Bleeker, 1849) }\end{array}$ & Gobiidae & Goby & Native & 12 & 2 & $2.4-6.8$ & $2-7$ \\
\hline $\begin{array}{l}\text { 16. Callogobius hastatus } \\
\text { (McKinney and Lachner, } \\
\text { 1978) }\end{array}$ & Gobiidae & Spearfin goby & Native & 0 & 3 & $3.8-6.2$ & $3-5$ \\
\hline
\end{tabular}




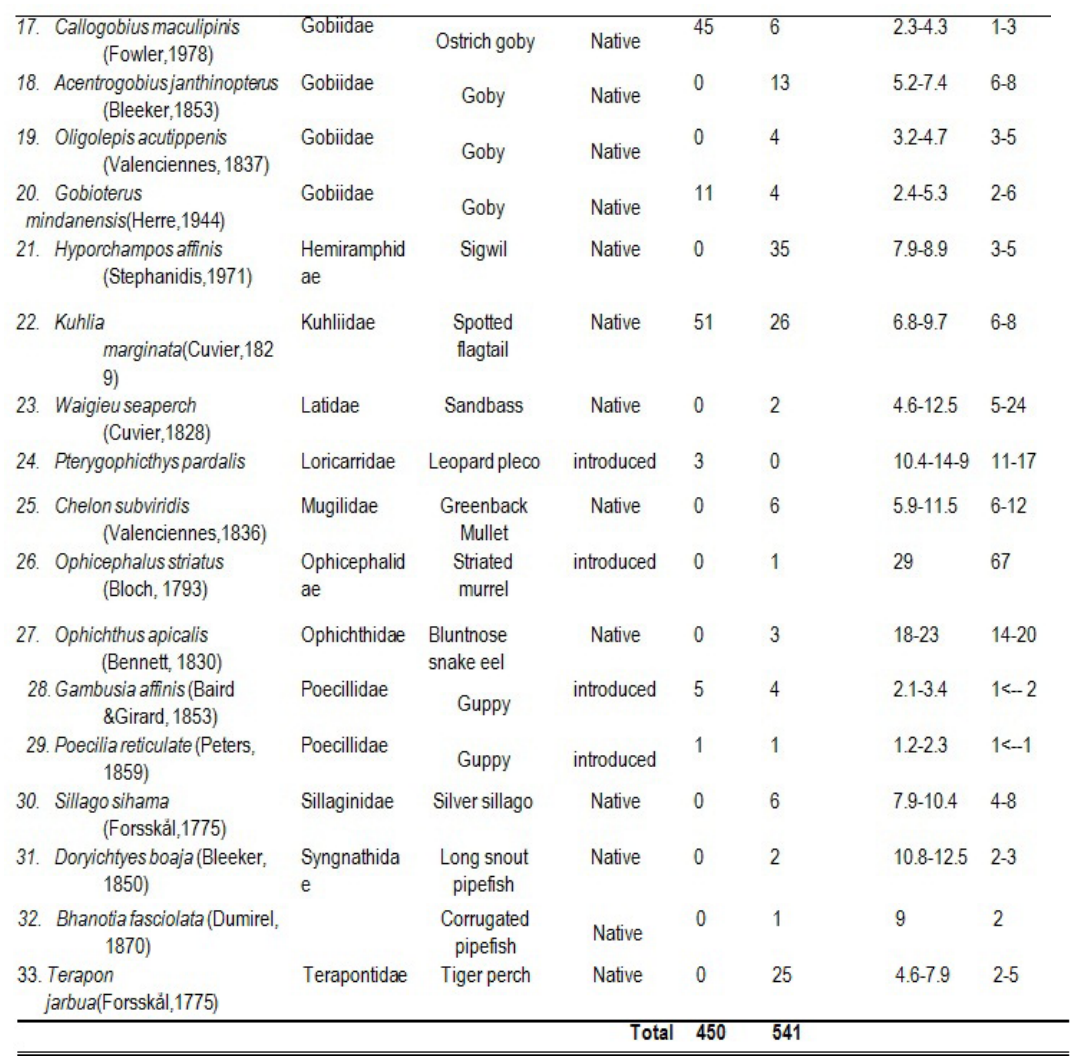

There was an increasing number of species and individuals from upper (S1) to down stations (S4) for both Dumagooc and Maug Rivers (Figure 4). The same pattern was observed by Guzman and Capaque (2014) in Bugang River where fish species richness followed an increasing trend from upper station to down station. A high number of fish species especially in the down stations of Dumagooc and Maug was attributed to the egression of estuarine fish species. The high species richness in the area was due to its location near the sea mouth with sandy and muddy substrate. Matillano and Atrero (2012), also recorded most individuals and species in a sandy-muddy habitats in Lake Manguao in Palawan Province. This substrate furnished a diverse habitat for different fish species (Robertson and Duke 1998). Meanwhile the lowest species richness recorded in the upper stations might be due to elevation, existing land use and the rocky substrate. 

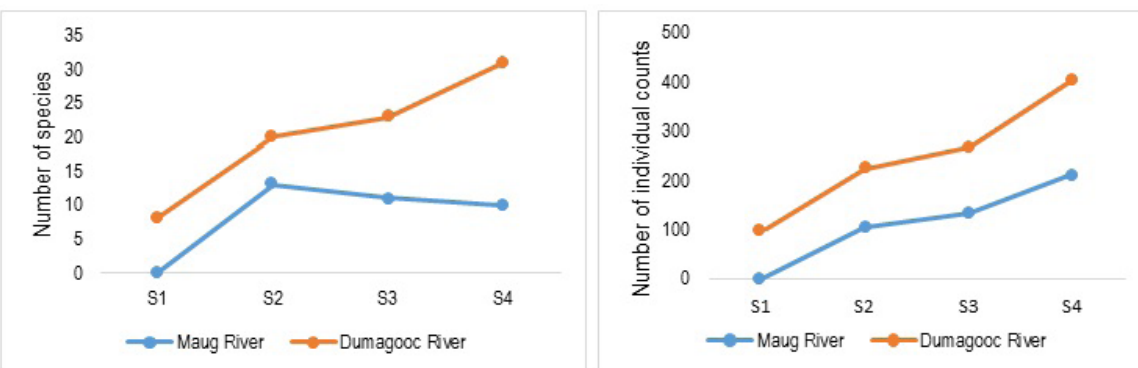

Figure 4. Fish Distribution Pattern along Study Stations at Dumagooc and Maug

Rivers, Mt. Hamiguitan Wildlife Sanctuary, Davao Oriental Mindanao

LTER site, Philippines (A. Number of Species, B. Number of Individuals)

Anguilla marmorata (Figure 5) was recorded in all stations of the Dumagooc River. This native fish is a facultative catadromous fishes, growing in estuaries or inland freshwater. When it becomes sexually mature, it migrates back to the ocean grounds to spawn before dying (Briones et al. 2007). However, Stiphonodon atropurpureus was noted only in the upper station (DU1). Even if it was observed that a high number of species was recorded in the down station this species was observed in clear streams and mainly feed on epiphyte and biofilm on rocks in the wild, and most survived with substrate that are normally with scattered jumbles of boulders (Mcdowall 2009). The upstream provide suitable environment for this species to survive. Moreover, most of the species recorded in Dumagooc River were estuarine species collected during high tide. Results were similar with the studies of Guzman and Capaque (2014) Matillano and Atrero (2012), Pacalioga et al. (2010) who found that more species and individuals were recorded in the down stations located near the sea and mangrove areas. Mangroves and aquatic plants serve as refuge from predations and opportunistic feeders (Abroguena et al. 2012). Aside from sandy and muddy substrate, mangroves and other aquatic plants create a suitable habitat for growth of fish larvae Faunce and Serafy (2006). This explains why most of the collected fish species in this study were generally smaller. 


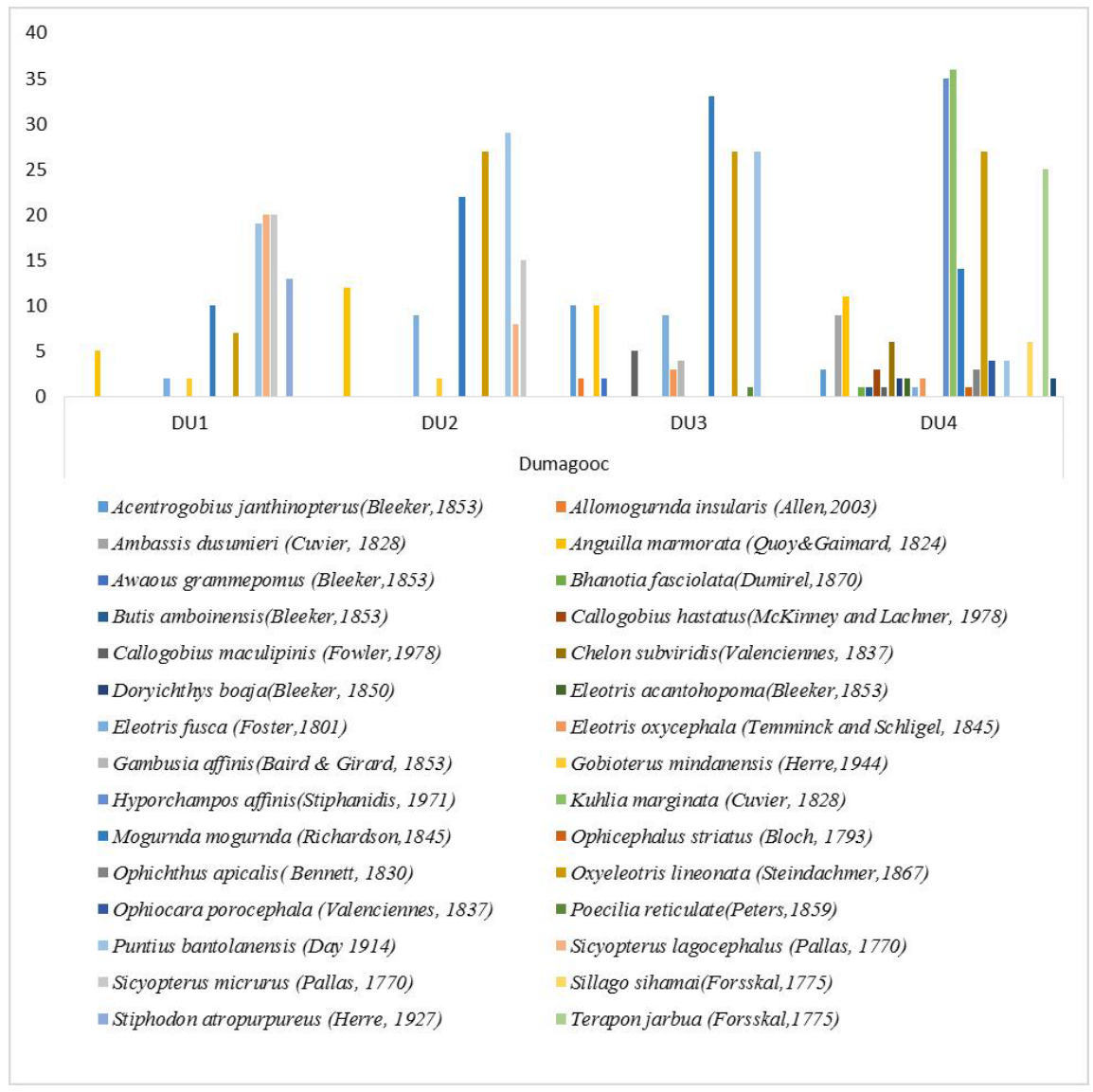

Figure 5. Fish Distribution Pattern along Study Stations at Dumagooc, Mt. Hamiguitan Wildlife Sanctuary,Davao Oriental Mindanao LTER Site, Philippines.

The endemic species of Puntius bantolanensis (Figure 6) was recorded in the Maug River from upper middle station (MA2) to down station (MA4). The introduced species of leopard pleco Pteryphicthys pardalis was noted only in the upper middle station (MA2). It was observed that there were more species recorded in the upper middle station of Maug River. This could be due to the agro forested area away from any human settlements where fish species could survive. However, another introduced species, Gambusia affinis and Poecilia reticulate, were noted in the lower middle stations (DU3 and MA3) of both rivers. 


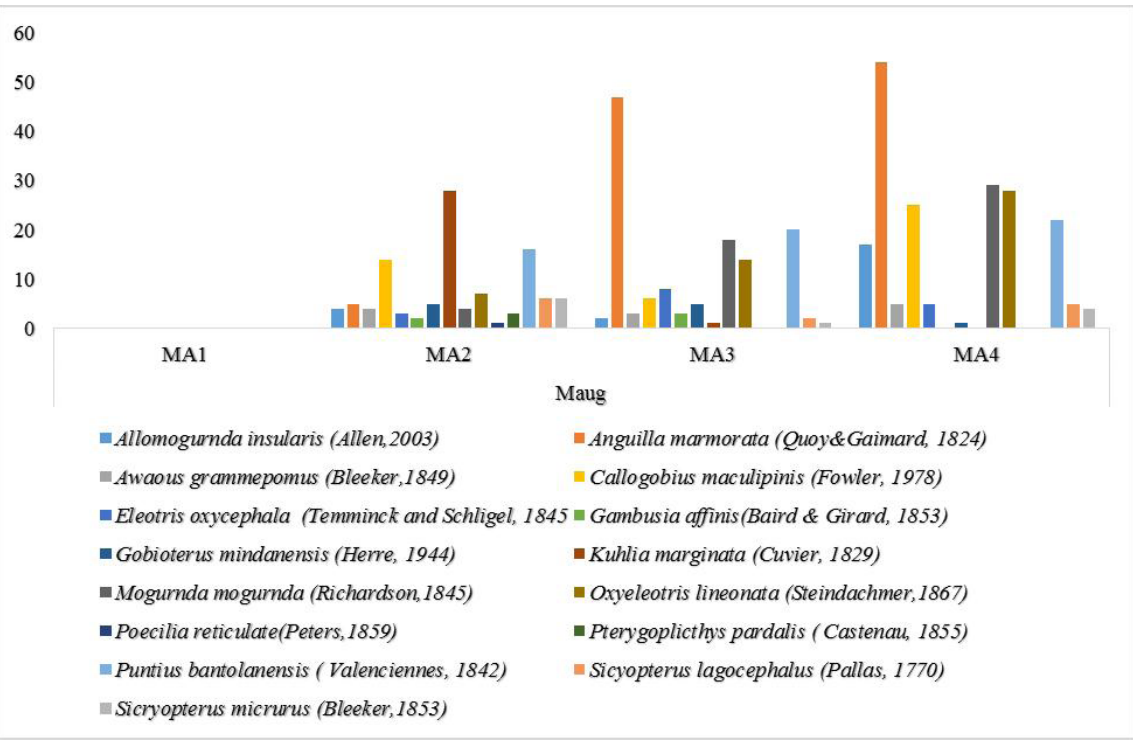

Figure 6. Fish Distribution Pattern along Study Stations at Maug Rivers,

Mt. Hamiguitan Wildlife Sanctuary,Davao Oriental Mindanao LTER Site, Philippines

In terms of species diversity, the Dumagooc River was more diverse (1.199) compared with Maug River (1.008). This could be due to the invasion of estuarine fish species in the down station (DU4) during high tide in Dumagooc River.

For species diversity, Dumagooc river had a higher species diversity compared with the result of Paller et al. (2010) in Mt. Makiling reserved forest where they recorded a 1.15 H' and lower with the study of Matillano and Atrero (2012) in Lake Manguao in Palawan which had a high species diversity of 1.25 H'.

Table 3. Fish Species Diversity in Two Rivers of Mt. Hamiguitan Range Wildlife Sanctuary (MHRWS) (February-May- October, 2015)

\begin{tabular}{lcc}
\hline \hline Index & Dumagooc & Maug \\
\hline Shannon H' Log Base 10. & 1.199 & 1.008 \\
\hline \hline
\end{tabular}




\section{CONCLUSIONS}

The two rivers in Mt. Hamiguitan Range Wildlife Sanctuary harbor a total of 33 species in 15 families with a total of 991 individuals throughout the sampling period. These rivers support one endemic species, 28 native species, and four introduced species. Fishes are well distributed in all stations of Dumagooc River with the downstream (DU4) having the highest fish species recorded. $A$. marmoratawas was noted in all the stations while Stiphonodon atropurpureus was confined in the upper stream (DU1). There were no fish recorded in the upper stream of Maug river. The endemic species of Puntius bantolanensis was noted from the upper middle stream (MA2) to downstream (MA4) while the invasive species of Pteryphicthys pardalis was collected only in the upper middle stream (MA2). Dumagooc River had a higher fish diversity $\left(\mathrm{H}^{\prime}=1.199\right)$ than Maug River with $(\mathrm{H}=1.008)$. Mt. Hamiguitan Range Wildlife Sanctuary has a very rich aquatic ecosystem that needs to be protected and conserved.

\section{ACKNOWLEDGMENTS}

Our sincere gratitude is extended to the Commission on Higher Education (CHED) for funding the research project. The logistic support extended to the project by Central Mindanao University (CMU), Local Government Unit (LGU) of San Isidro, Barangay Officials and "Bantay Gubat" of the Municipalities of San Isidro and Governor Generoso is hereby acknowledged. A special appreciation is also extended to the Protected Area Wildlife Division (PAWD) of DENR XI for the gratuitous permit issued for the research and collection of some specimen samples.

\section{LITERATURE CITED}

Abroguena JBR, Bagarinao TV, Chicharo L. 2012. Fish habitat in a small, human-impactedSibunag mangrove creek (Guimaras, Philippines: a basis for mangrove resource enhancement). Ecohydrology and hydrolobiology. 12.4:311-319

Amoroso V, Aspiras R. 2011. Hamiguitan Range: A sanctuary for native flora. Saudi Journal of Biological Sciences, 18, 7-15. 
Biodiveristy Professional Version 2. 1997. Natural history museum and the Scottish association for marine science.

Briones AA, Yambot AV, Shiao JC, Iizuka Y, Tzeng WN. 2007. Migratory pattern and habitat use of tropical ells Anguilla spp. (Teleostie: Anguilliformis. Anguillidae) in the Philippines as revealed by otolith microchemistry. The raffles bulletin of zoology. Academia sinica and national university. Singapore.14:pp141-149.

Bucol AA, Carumbana EE. 2010. Checklist of fishes found in the fresh and brackish water of Negros and Siquijor, Philippines. Asian Journal of Biodiversity. 1:1.

Faunce CH, Serafy JE. 2006. Mangroves as fish habitat: 50 years of field studies. Marine ecology progress series. 308:pp 1-18.

Froese R, Pauly D Ed. 2016. Fishbase. World Wide Web electronic publication. www.fishbase.org.version(01/2016)

Google Earth. 2014. Map of Governor Generoso.06041.130,.126007.720. 197 masl. http:// www.google.com/earth/index.html>.accessed August, 2015

Guzman AMT, Capaque TPV. 2014. Inventory of ecologically important fish species in Bugang River, Philippines. Aquaculture, aquarium, conservation and legislation international. Journal of Bio flux Society.

Herre AWCT. 1953. A checklist of Philippines fishes. Research report. Washington, D.C. fish and wildlife service, Unit of States Department Interior, government publishing office. p 977.

Helfman GS. 1999. Behavior and fish conservation: introduction, motivation ans overview. Environ boil fish, 55:7-12.

Hubilla MFK, Primavera J. 2007. Janitor fish, Pterygoplicthysdisjunctivus in Agusan marsh: a threat to freshwater biodiversity. Journal of environmental science management.10:1. pp10-23. 
Khan AM, Ali Z, Shelly SY, Ahmad Z, Mirza MR. 2011. Aliens: a catastrophe for native freshwater fish diversity in Pakistan. The journal of animal and plant science. pp 435-440.

Mcdowall RM. 2009. Early hatch: a strategy for safe downstream larval transport in amphidromous gobies. Review in fish biology and fisheries.19.1:1-8.

Matillano JD, Atrero LO. 2012. Conserving endemic and globally threatened fishes in Lake Manguao, Palawan, Philippines. To promote appropriate management/ conservation and outreach initiates for the globally threatened fishes of Lake Manguao . CLP. Prog. No.0347311. Implemented in collaboration with Western Philippines University and the Municipality Government of Taytay.

Medina MN, Colong R, Villanueva RJT, Cabras AA. 2016. Threatened flora of Mt. Hamiguitan range wildlife sanctuary. In collaboration with the rufford small grants foundation, University of Mindanao and Department of environment and natural resources.

Pacalioga JO, Linaugo JD, Menes CC, Patiluna MLE, Turbanos FM, Bucol AA. 2010.Fishes and macroinvertebrates of Bago River, Negros Occidental, Philippines. Silliman Journal 51(1):53-77.

Paller VGU, Labatos BV, Lontoc BM, Matalog OE, Ocampo PP. 2011. Freshwater fish fauna in watersheds of Mt. Makiling forest reserve, Laguna, Philippines. Philippine Journal of Science.140:195-206.

Quimpang VT, Opiso EM, Cudal MC, Coquilla KL, Buot GA, Forten RRC, Bruno AGT, Amoroso, V.B. 2015. Assessment and monitoring of fish species in mountain streams and lakes of Mindanao LTER sites. Asean scientific journals. 6.1. Available at aseanscientificjournal.com/publication/ index.php/ajob/search/titles.

Relox RE, Leaño EP, Camino FA. 2011. Avifaunal assemblage in Mt. Hamiguitan, Davao oriental, Mindanao Island, Philippines. Journal of environmental science and management. 14:1.pp 1-11. 
Robertson AI, Duke NC, 1987. Mangroves as nursery sites: comparisons of the abundance and species composition of fish and crustaceans in mangroves and other nearshore habitats in tropical Australia. Marine Biology 96:193-205. R 